\title{
Tumor Hypoglycemia: Relationship to High Molecular Weight Insulin-like Growth Factor-II
}

\author{
E. T. Shapiro, ${ }^{\star}$ G. I. Bell,,5 K. S. Polonsky, ${ }^{\star}$ A. H. Rubenstein, ${ }^{\star}$ M. C. Kew," and H. S. Tager \\ ${ }^{*}$ Pritzker School of Medicine, Department of Medicine, ${ }^{\ddagger}$ Howard Hughes Medical Institute, ${ }^{\S}$ Department of Biochemistry and \\ Molecular Biology, University of Chicago, Chicago, Illinois 60637; "University of Witwatersrand, Department of Medicine, \\ Johannesburg 2193, South Africa
}

\begin{abstract}
The mechanism of tumor-associated hypoglycemia was examined in 11 patients with hepatocellular carcinoma, 6 of whom presented with severe hypoglycemia and 5 in whom plasma glucose was persistently normal. Serum insulin levels in the hypoglycemic patients were low. Although total serum insulinlike growth factor II (IGF-II) levels in both groups of tumor patients were lower than normal, tumor tissue from hypoglycemic patients contained levels of IGF-II mRNA that were 10-20-fold higher than those present in normal liver.

IGF-II immunoreactivity consisted in all cases of a mixture of both higher molecular weight forms and material having the character of IGF-II itself. The former comprised a greater proportion of total IGF-II, in patients with hypoglycemia. Studies to characterize the interactions of IGF-II with serum proteins showed that $(a)$ the radiolabeled peptide bound to an $\sim 40,000-D$ protein in sera from both hypoglycemic patients and normal subjects, $(b)$ sera from hypoglycemic patients and normal subjects had similar capacity to bind the radiolabeled peptide, and (c) the apparent affinities of serum binding proteins for IGF-II were the same for both hypoglycemic patients and normal subjects. Whereas, acid extracted, tumor-derived IGF-II immunoreactive peptides with low or intermediate molecular weights bound to serum proteins in a manner indistinguishable from that of IGF-II itself, the highest molecular weight IGF-II immunoreactive peptide exhibited negligible ability to compete for radiolabeled ligand binding to serum proteins. The low affinity of serum binding proteins for this component suggests that high molecular weight IGF-II immunoreactivity might circulate free and be available for interaction with cell-surface receptors. (J. Clin. Invest. 1990. 85:1672-1679.) IGF-II • tumor hypoglycemia
\end{abstract}

\section{Introduction}

It is well known that certain tumors may be associated with hypoglycemia. McFadzean and Yeung separated the occurrence of hypoglycemia in Chinese patients with hepatocellular

Presented in abstract form at the National Meeting for the American Federation of Clinical Research, May 1988, Washington, DC. (Clin. Res.) 36:490A, 1988.

Address reprint requests to Dr. Polonsky, University of Chicago, Department of Medicine, Box 435, 5841 S. Maryland Ave., Chicago, IL 60637

Received for publication 23 March 1989 and in revised form 30 November 1989.

J. Clin. Invest.

(C) The American Society for Clinical Investigation, Inc.

0021-9738/90/05/1672/08 \$2.00

Volume 85, May 1990, 1672-1679 carcinoma into two distinct types (1). Patients with type A hypoglycemia developed mild reductions in plasma glucose which were readily treated, occurred during the terminal stages of the illness, and were associated with cachexia. In contrast, patients with type B hypoglycemia demonstrated marked decrements in glucose levels that were more difficult to control and that occurred in patients in whom cachexia was not a feature. Despite extensive study however, the factors responsible for the fall in blood glucose in the latter group of patients are unknown. Suggested causes include either decreased hepatic glucose production or increased glucose uptake either by the tumor or the periphery, or both $(2,3)$.

Insulin levels have been consistently low in cases of tumor-associated hypoglycemia and, therefore, production of an insulin-like factor by the tumor has been suggested as the cause of the enhanced peripheral glucose uptake (4). Thus Megyesi et al. (5, 6), Hyodo et al. (7), and Gorden et al. (8), using a radioreceptor assay (RRA), ${ }^{1}$ identified increased serum nonsuppressible insulin-like activity (NSILA) in patients presenting with various tumors associated with hypoglycemia. It is now known that this receptor assay detects primarily IGF-II, and Daughaday et al. found elevated serum IGF-II levels in 10 of 14 patients with this syndrome using a sensitive RRA (9). However, Zapf et al. (10) and Widmer et al. (11) subsequently found no elevation in serum IGF-II levels in patients with tumor hypoglycemia using either an RRA or immunoassay (RIA). High concentrations of IGF-II were recently reported by Daughaday et al. (12) in an extract of a leiomyosarcoma associated with recurrent hypoglycemia. It is important that a large proportion of the IGF-II immunoreactivity was of higher molecular weight in both the tumor and the patient's serum, and higher than expected amounts of the corresponding mRNA were identified in tumor tissue. Although IGF-II circulates bound to serum proteins (13-15) and although total serum IGF-II levels did not decrease after removal of the tumor, tumor resection was associated with remission of hypoglycemia and with decreased amounts of higher molecular weight IGF-II in serum.

In this report, we describe 11 patients with hepatocellular carcinoma including a group of 6 patients presenting with severe recurrent hypoglycemia (corresponding to the type $B$ patients described above) and a group of 5 who were normoglycemic. The availability of limited amounts of tumor and serum from these patients enabled us to determine if there were factors specific to the hypoglycemic group that might account for the low blood glucose. Studies involving analysis of tumor IGF-II mRNA and gel filtration of IGF-II immunoreactive peptides extracted from serum in both groups of pa-

1. Abbreviations used in this paper: IGF-II, insulin-like growth factorII; NSILA, nonsuppressible insulin-like activity; RRA, radioreceptor. 
tients, and characterization of IGF-II-related peptides from tumors of hypoglycemic patients, suggest a possible causal relationship between products of the IGF-II gene and tumor hypoglycemia.

\section{Methods}

\section{Subjects}

Clinical details of the 11 male patients with hepatocellular carcinoma are shown in Table I. Their ages ranged between 14 and $72 \mathrm{yr}$; applicable treatment regimens varied from one patient to another. The presence of hypoglycemia resulted in neuropsychiatric manifestations including aggressive behavior, confusion, seizures, and coma. Diagnosis of the underlying tumor was made during the course of investigation into the cause of hypoglycemia. For the hypoglycemic patients, serum was collected during episodes of low plasma glucose. Blood samples were obtained from normoglycemic patients at random. Only a single serum sample was available from each patient. The plasma glucose levels in the hypoglycemic group ranged from 0.1 to $1.6 \mathrm{mmol} / \mathrm{liter}$ at the time of clinical presentation. These patients required continuous infusion of intravenous glucose in order to maintain plasma glucose levels within the normal range. Death occurred rapidly ( $2 \mathrm{~d}$ to $9 \mathrm{wk}$ after presentation) in all the patients. In contrast, in the normoglycemic group, the average plasma glucose was $>4 \mathrm{mmol} / \mathrm{liter}$ and no episodes of hypoglycemia were observed. An additional 19-yr-old patient with omental hemangiopericytoma associated with hypoglycemia (plasma glucose $1.3 \mathrm{mmol} / \mathrm{liter}$ ) was examined. The patient remained normoglycemic after resection of the tumor.

Tumors and adjacent nonneoplastic liver were obtained from the six hypoglycemic patients with hepatocellular carcinoma. Only tumor samples were available from the five normoglycemic patients. $30-40 \mathrm{~g}$ of tissue was collected from each subject. Liver tissue was obtained after partial hepatectomy or at necropsy $<1 \mathrm{~h}$ after death. Upon removal, the tissues were frozen immediately in liquid nitrogen and then stored at $-70^{\circ} \mathrm{C}$ until analyzed.

Table I. Clinical Characteristics and Concentrations of Glucose and Insulin

\begin{tabular}{ccccc}
\hline Patient & Age & Clinical presentation & Glucose & Insulin \\
\hline$y r$ & & mmol/liter & pmol/liter
\end{tabular}

Hepatocellular carcinoma

Hypoglycemic

\begin{tabular}{|c|c|c|c|c|}
\hline 1 & 19 & Confusion & 0.5 & 21 \\
\hline 2 & 45 & $\begin{array}{l}\text { Aggressive behavior, } \\
\text { seizure, coma }\end{array}$ & 0.8 & NS \\
\hline 3 & 24 & Coma & 1.0 & NS \\
\hline 4 & 25 & $\begin{array}{l}\text { Aggressive behavior, } \\
\text { coma }\end{array}$ & 0.1 & 41 \\
\hline 5 & 39 & Coma & 0.9 & NS \\
\hline 6 & 25 & Seizure & 1.6 & NS \\
\hline \multicolumn{5}{|c|}{ Normoglycemic } \\
\hline 7 & 14 & & 6.5 & 179 \\
\hline 8 & 72 & & 6.2 & 62 \\
\hline 9 & 58 & & 6.6 & 166 \\
\hline 10 & 35 & & 4.5 & 7 \\
\hline 11 & 41 & & 6.2 & 7 \\
\hline
\end{tabular}

NS, insulin levels in these patients were below the sensitivity of the assay.

\section{Procedures}

Analysis of RNA. RNA was isolated from $4 \mathrm{~g}$ of tissue (liver, hepatoma, hemangiopericytoma, term placenta, or Hep G2 cells) using the guanidine thiocyanate-cesium chloride procedure (16). The concentration of RNA was determined by absorption at $260 \mathrm{~nm}$. $20 \mu \mathrm{g}$ of total RNA from each sample was immobilized on a nitrocellulose membrane using a slot-blot apparatus (Minifold II; Schleicher and Schuell, Keene, $\mathrm{NH}$ ). The filters were hybridized as previously described (17) with ${ }^{32} \mathrm{P}$-labeled inserts from the following human cDNA clones: IGF-I, phigfl (18); IGF-II, phigf2 (18); and liver glucose transporter, phHTL-1 (19). Transcript sizes were determined by the Northern blotting procedure after separation of denatured RNA in a $1 \%$ agarose gel containing $0.66 \mathrm{M}$ formaldehyde (20). All filters were washed under conditions of high stringency $(1.5 \mathrm{mM} \mathrm{NaCl}, 0.15 \mathrm{mM}$ sodium citrate and $0.1 \%$ SDS at room temperature for $1 \mathrm{~h}$ and then $65^{\circ} \mathrm{C}$ for $1 \mathrm{~h}$ ) before autoradiography. The relative abundance of each transcript was determined by laser densitometry of the autoradiograph. IGF-II mRNA levels were also determined using an RNase-protection assay (21). The riboprobe vector was a derivative of pGEM-3Z (Promega, Madison, WI) containing an 803-bp Pst I fragment of phigf2 (18), which included $267 \mathrm{bp}$ of 5'-untranslated region of the liver-type IGF-II transcript, $540 \mathrm{bp}$ coding for the human IGF-II precursor and 25 bp of 3'-untranslated region. The vector was linearized with Sal I before preparing antisense RNA using the SP6 promoter. The 300 nucleotide antisense RNA included 21 nucleotides of the vector and 279 nucleotides complementary to IGF-II mRNA. After solution hybridization and RNase digestion (21), the protected fragments were separated by electrophoresis on a $5 \%$ acrylamide $/ 50 \%$ urea denaturing gel. Subsequent to autoradiography, the relative abundance of the protected fragment was quantified by laser densitometry. Data reported represent the mean of duplicate experiments. Liver mRNA from a normal individual who died accidentally was used as the control for all studies and was examined on many different occasions.

Measurement of glucose, insulin, GH, and IGF levels. Plasma glucose was measured by the glucose oxidase method with a glucose analyzer (Beckman II; Beckman Instruments, Inc., Fullerton, CA). Serum insulin was assayed by a double antibody technique (22). IGF-I levels were measured using a specific RIA after binding proteins had been extracted as previously described $(23,24)$. Growth hormone concentrations were measured by RIA (Serono Diagnostics, Norwell, MA). RIA of IGF-II was performed using recombinant human IGF-II, ${ }^{125}$ I-labeled IGF-II (Eli Lilly, Indianapolis, IN) and a monoclonal antibody to IGF-II (Amano, Troy, VA) in $0.5 \mathrm{ml}$ of $0.1 \mathrm{M}$ Tris, $0.05 \mathrm{M}$ $\mathrm{NaCl}$, and $1 \mathrm{mg} / \mathrm{ml}$ bovine serum albumin (pH 7.4) essentially as described (25), except that precipitation was performed by addition of an equal volume of $24 \%$ polyethylene glycol (8000) and $20 \mu \mathrm{l} 1 \%$ bovine gamma globulin $(10 \mathrm{mg} / \mathrm{ml}$ buffer). Total IGF-II levels in acidextracted serum and tumor tissue were determined as previously described (12). Gel filtration of tumor extracts and serum was performed as described (12).

Analysis of IGF-II from tumor tissue. Approximately $25 \mathrm{~g}$ of tumor tissue obtained from subjects $1,2,5$, and 6 (Table I) was homogenized in $6 \mathrm{vol}$ of $74 \%$ ethanol, $0.05 \mathrm{M} \mathrm{HCl}$ and kept at $4^{\circ} \mathrm{C}$ for $2 \mathrm{~h}$. After centrifugation, the supernatant was adjusted to $\mathrm{pH} 5.0$ with ammonium hydroxide, $10 \mathrm{vol}$ of acetone was added, the mixture was kept at $4^{\circ} \mathrm{C}$ for $12 \mathrm{~h}$, and the precipitate (collected by centrifugation) was dissolved in $10 \mathrm{ml}$ of $3 \mathrm{M}$ acetic acid containing $1.0 \mathrm{M} \mathrm{NaCl}$; insoluble material was removed by centrifugation. The supernatant was then passed through a $95 \times 2.5 \mathrm{~cm}$ Bio-gel P-30 column equilibrated with 3 $M$ acetic acid. 3-ml fractions were collected at a rate of $21-24 \mathrm{ml} / \mathrm{h}$ and the concentration of IGF-II in each fraction was determined by radioimmunoassay. Although it is difficult to assess recovery of IGF-II-related peptides from the gel filtration column (due to the presence of IGF binding proteins and interfering substances in the initial extract), control studies have demonstrated $85 \%$ recovery for peptides having similar size and characteristics.

Gel filtration profiles of tumor tissue demonstrated that approximately equal amounts of IGF-II immunoreactivity eluted as higher 
and lower molecular weight forms. The fractions corresponding to higher and lower molecular weight material were pooled separately and gel filtration was repeated for each pool. IGF-II immunoreactivity as well as optical absorbance at $275 \mathrm{~nm}$ was measured in each fraction. Fraction numbers 56, 64, and 70 from the resulting elution profile of higher molecular weight IGF-II material and fraction number 78 from the lower molecular weight profile were lyophilized and then further analyzed by reverse-phase HPLC in a gradient of $20-40 \%$ acetonitrile in triethylammonium phosphate buffer over $60 \mathrm{~min}$ as previously described (26). 1-ml fractions were collected and IGF-II immunoreactivity was determined in each fraction.

IGF-II binding studies. The size and heterogeneity of serum proteins to which IGF-II binds was determined as follows. $50 \mu \mathrm{l}$ of serum from two normal subjects and two patients (patients 4 and 5, Table I) was incubated with $\sim 100,000 \mathrm{cpm}$ of ${ }^{125} \mathrm{I}-\mathrm{IGF}-\mathrm{II}$ at $4^{\circ} \mathrm{C}$ for $12 \mathrm{~h}$, and then gel filtered on a $0.9 \times 90 \mathrm{~cm}$ Ultrogel AcA 44 column (IBF Biotechnics, Inc., Savage, MD). Samples were eluted with buffer (0.1 $\mathrm{M}$ Tris, $0.05 \mathrm{M} \mathrm{NaCl}, 1 \mathrm{mg} / \mathrm{ml} \mathrm{BSA}, \mathrm{pH} 7.4$ ) at a flow rate of 8-10 $\mathrm{ml} / \mathrm{min}, 0.5-\mathrm{ml}$ samples were collected, and radioactivity was determined in a gamma counter. To determine the binding capacity of serum for IGF-II, increasing volumes of serum $(0.1-50 \mu \mathrm{l})$ from three normal subjects and three patients with hypoglycemia (patients 4, 5, and 6, Table I) were incubated with $\sim 12,000 \mathrm{cpm}$ of ${ }^{125} \mathrm{I}-\mathrm{IGF}-\mathrm{II}$ for 12 h at $4^{\circ} \mathrm{C}$ in $500 \mu \mathrm{l}$ buffer $(0.1 \mathrm{M}$ Tris, $0.05 \mathrm{M} \mathrm{NaCl}, 1 \mathrm{mg} / \mathrm{ml} \mathrm{BSA}, \mathrm{pH}$ 7.4). Bound IGF-II was precipitated with an equal volume of $24 \%$ polyethylene glycol (8000) and $20 \mu \mathrm{l}$ of $1 \%$ bovine gamma globulin. Experiments were performed in duplicate.

For analysis of the affinity of IGF-II for serum binding proteins, sera from three normal, healthy subjects $(1 \mu l)$ and three patients with hypoglycemia (patients 4, 5, and 6, Table I, $2 \mu \mathrm{l}$ ) were incubated with $\sim 12,000 \mathrm{cpm}$ of ${ }^{125} \mathrm{I}-\mathrm{IGF}-\mathrm{II}$ and progressively increasing concentrations of IGF-II (0.1-100 ng) in $500 \mu$ l of the buffer described above. Bound radioactivity was precipitated as described above. To analyze the interactions of serum binding proteins with the various molecular forms of IGF-II detected in tumor extracts, fraction numbers 56, 64, and 70, which represent different regions of the large molecular weight IGF-II immunoreactivity profile (Fig. $3 a$ ), and fraction number 78 from the small molecular weight profile (Fig. $3 \mathrm{~b}$ ) were lyophilized and dissolved in buffer. $1 \mu \mathrm{l}$ of serum from a healthy individual or $2 \mu \mathrm{l}$ of patient serum (patient 6, Table I) was incubated with progressively increasing concentrations of IGF-II immunoreactivity (0.1-50 ng), assessed by RIA of these four fractions, after extraction of immunoreactive components into buffer, or IGF-II in the presence of $\sim 12,000$ $\mathrm{cpm}^{125} \mathrm{I}$-IGF-II in a volume of $500 \mu \mathrm{l}$ buffer. After incubation at $4^{\circ} \mathrm{C}$ for $12 \mathrm{~h}$, bound radioactivity was precipitated as described above.

\section{Results}

Insulin, GH, and IGF-I concentrations. Serum insulin levels in the hypoglycemic patients were suppressed, and in four of the patients, were below the sensitivity of the assay (Table I). The low insulin levels were appropriate for the prevailing plasma glucose levels, suggesting an alternative cause for the hypoglycemia. Patients who were normoglycemic had variable serum insulin levels, ranging from 7 to $179 \mathrm{pmol} / \mathrm{liter}$. GH levels in four patients with hypoglycemia (subjects $3,4,5$, and 6 , Table I) were $15.4,7.2,6.3$, and $2.7 \mathrm{mU} /$ liter, respectively (normal, $<10 \mathrm{mU} /$ liter) and $\mathrm{GH}$ levels in four patients who were normoglycemic (subjects $7,8,9$, and 11 , Table I) were $1.5,0.4$, 0.6 , and $28.0 \mathrm{mU} /$ liter, respectively. Insufficient serum was available for determination of $\mathrm{GH}$ concentrations in the other patients. Serum IGF-I levels were similar in both groups of patients with hepatocellular carcinoma, averaging $22 \pm 5 \mu \mathrm{g} /$ liter and $29 \pm 9 \mu \mathrm{g} /$ liter for the hypoglycemic and normoglycemic groups, respectively (normal range $150-480 \mu \mathrm{g} / \mathrm{liter}$ ).
Analysis of IGF-II $m R N A$. IGF-II mRNA levels were specifically elevated 10-20-fold in tumor tissue from all the patients with hypoglycemia, compared to normal adult liver or adjacent noninvolved liver tissue (Fig. 1). (Although IGF-II mRNA levels were also slightly elevated in the adjacent liver samples from hypoglycemic patients 1 and 6, reevaluation of these samples revealed microscopic infiltration by tumor cells). In contrast, IGF-II mRNA levels in tumors from normoglycemic patients were $0.1-1.3$-fold of the level observed in normal adult liver. IGF-I and liver glucose transporter mRNA levels were increased $\sim 10$-fold each compared with normal adult liver in one subject with hepatocellular carcinoma and hypoglycemia (patient 5, Table I). The serum IGF-I concentration in this patient was $48 \mu \mathrm{g} /$ liter. Liver glucose transporter mRNA levels were also increased two- to threefold in patient 3 (Table I). The abundance of transcripts for mRNA for these two proteins were similar to normal adult liver tissue in all other hepatomas. Thus, only IGF-II mRNA levels were consistently elevated and only in hypoglycemic patients. RNA blotting (data not shown) demonstrated the presence of major IGF-II mRNA transcripts of 6.0 and $4.8 \mathrm{~kb}$ in several of the tumors from hypoglycemic patients, as well as one of the tumors associated with normoglycemia. Thus the sizes of the

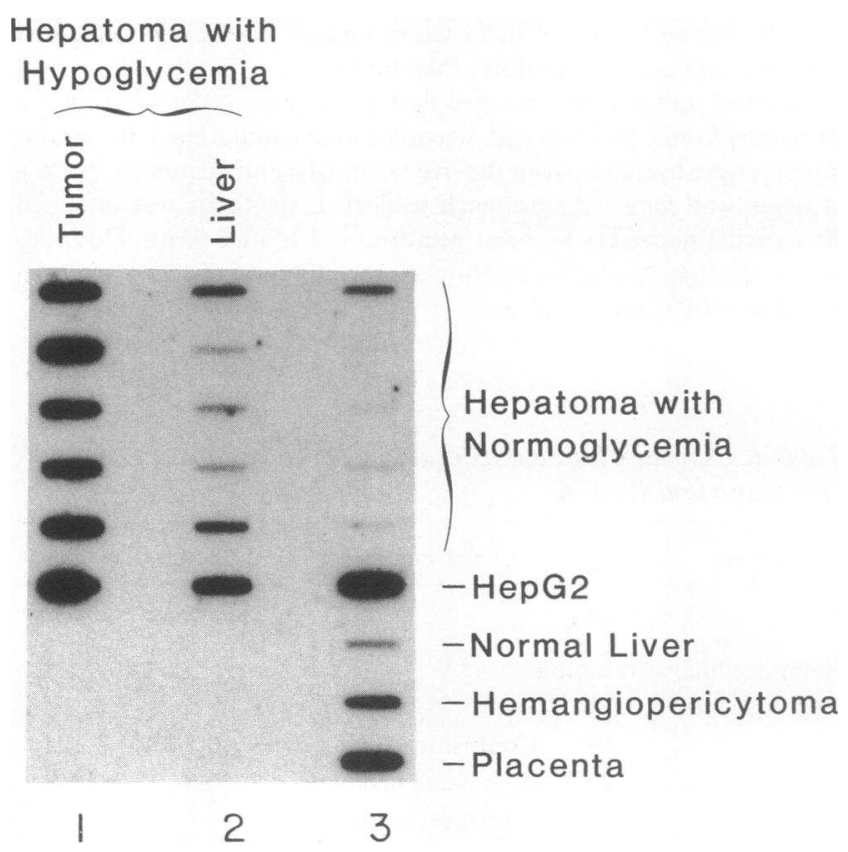

Figure 1. IGF-II mRNA levels in tumor and normal tissues. $20 \mu \mathrm{g}$ of RNA from each sample was denatured and immobilized on a nitrocellulose filter using a slot blot apparatus. After hybridization with a ${ }^{32} \mathrm{P}$-labeled human IGF-II cDNA probe, the filter was exposed to $\mathbf{x}$-ray film. The autoradiogram indicates hybridization to RNA prepared from the tumor and adjacent liver tissue of six patients with hepatocellular carcinoma (hepatoma) associated with hypoglycemia (lanes $I$ and 2; from top to bottom, patients 1-6, Table I) as well as from five hepatocellular carcinomas obtained from normoglycemic subjects (lane 3; from top to bottom, patients 7-11, Table I). For comparison, hybridization to RNA isolated from a 19-yr-old male presenting with a hemangiopericytoma and associated hypoglycemia is also shown. In addition, the hybridization to RNA from HepG2 cells, normal liver (from a healthy subject who died accidentally) and term placenta are shown as controls. 
IGF-II transcripts in the hepatocellular carcinomas and the hemangiopericytoma associated with hypoglycemia appeared to be similar to those in tumors from normoglycemic individuals and identical in size to those present in placenta. Since the IGF-II mRNA from several of the hypoglycemic tumors was heterogeneous, indicating that it may have been partially degraded, the abundance of IGF-II mRNA in normal liver and hypoglycemic tumor tissue was also determined using an RNase-protection assay (Fig. 2). The increased abundance of IGF-II mRNA transcripts present in tumor tissue (relative to healthy liver) was similar in the RNase-protection and slot blot assays. This result thus confirms that specific IGF-II mRNA is indeed elevated in tumors from hypoglycemic patients.

Analysis of IGF-II immunoreactivity. Total IGF-II immunoreactivity in serum obtained from the patients with hepatocellular carcinoma who were hypoglycemic was $363 \pm 62 \mu \mathrm{g} /$ liter (range 179-568 $\mu \mathrm{g} /$ liter); values for those who were normoglycemic were $112 \pm 32 \mu \mathrm{g} /$ liter; (range 46-217 $\mu \mathrm{g} /$ liter). Although the difference between IGF-II levels in the two groups was statistically significant $(P<0.05)$, the levels in both groups were less than normal (normal range 330-1,080 $\mu \mathrm{g}$ / liter, see reference 12). Gel filtration of serum samples by standard methods (12) demonstrated considerable size heterogeneity of the IGF-II immunoreactivity, a result consistent with previous findings in a patient with a leiomyosarcoma and hypoglycemia (12). In patients who had hepatocellular carcinomas associated with hypoglycemia $48-72 \%$ of the serum IGF-II immunoreactivity eluted earlier than the mature IGF-II $7.5 \mathrm{kD}$ standard suggesting the presence of a larger molecular weight form of IGF-II. In patients with hepatocellular carcinoma who were normoglycemic $6-40 \%$ of IGF-II immunoreactivity eluted as larger forms. Gel filtration of normal serum revealed no detectable higher molecular weight IGF-II immunoreactivity.

Total IGF-II concentrations measured on extracts of tumors from patients with hepatocellular carcinoma were $130 \pm 33 \mathrm{ng} / \mathrm{g}$ (range, $30-264 \mathrm{ng} / \mathrm{g}$ ) and $22 \pm 2 \mathrm{ng} / \mathrm{g}$ (range, $16-28 \mathrm{ng} / \mathrm{g}$ ) in the hypoglycemic and normoglycemic groups, respectively. Gel filtration of these tumor extracts demonstrated that the IGF-II immunoreactivity was similarly heterogeneous in size. To define the nature of IGF-II immunoreactivity identified by gel filtration in greater detail, the immunoreactivity eluting as larger and smaller molecular weight forms, from the tumors of four patients $(1,2,5$, and 6, a total of $100 \mathrm{~g}$

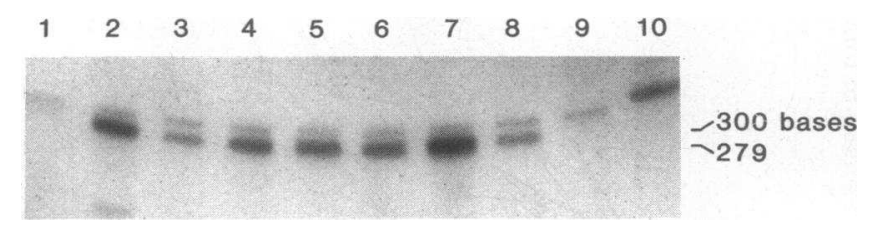

Figure 2. Solution hybridization/RNase protection assay. Solution hybridization was performed using a 300-base IGF-II riboprobe, complementary to 279 bases of IGF-II coding region and 21 bases of pGEM 3-Z plasmid sequence. $1 \mu \mathrm{g}$ of total RNA from normal healthy liver (lane 1), tumorous liver from patients with hypoglycemia (lanes 2-7 representing patients $1,2,5,3,4$, and 6 , respectively, Table I) or a hemangiopericytoma from a 19 -yr-old male presenting with hypoglycemia (lane 8) was hybridized to the Riboprobe. Lane 9, probe digested with RNase, lane 10, probe alone. The upper band represents probe resistant to digestion. tumor), was pooled and gel filtration was repeated separately for these small and large molecular weight forms. Fig. 3 illustrates the resulting IGF-II immunoreactivity measured in the gel-filtered fractions. The immunoreactive profile observed after gel filtration of the larger molecular weight form revealed the presence of at least three major components, whereas the elution profile of the smaller molecular weight form appeared to be homogeneous. It is important that $(a)$ even the highest molecular weight component was well separated from that region of the gel filtration profile in which IGF binding proteins would be expected to elute, and $(b)$ our use of polyethylene glycol precipitation during RIA precluded the erroneous assessment of IGF-II/binding protein complexes as IGF-II immunoreactivity in the inhibition assay. Calibration of the column with standard proteins suggested that the higher molecular weight forms of IGF-II had molecular weights in the range 10,000-17,000.

To analyze further these different molecular forms of IGFII, fraction numbers 56, 64, and 70 from the profile in Fig. $3 a$ and fraction number 78 from the profile represented in Fig. $3 b$ were examined by reverse-phase HPLC. Although the peptides sometimes eluted as broad peaks indicative of heterogeneity, all of these components eluted near the IGF-II standard, even during use of a shallow acetonitrile gradient (date not shown). It would therefore appear that either the carboxyl-terminal extensions expected on IGF-II precursors and conversion in-

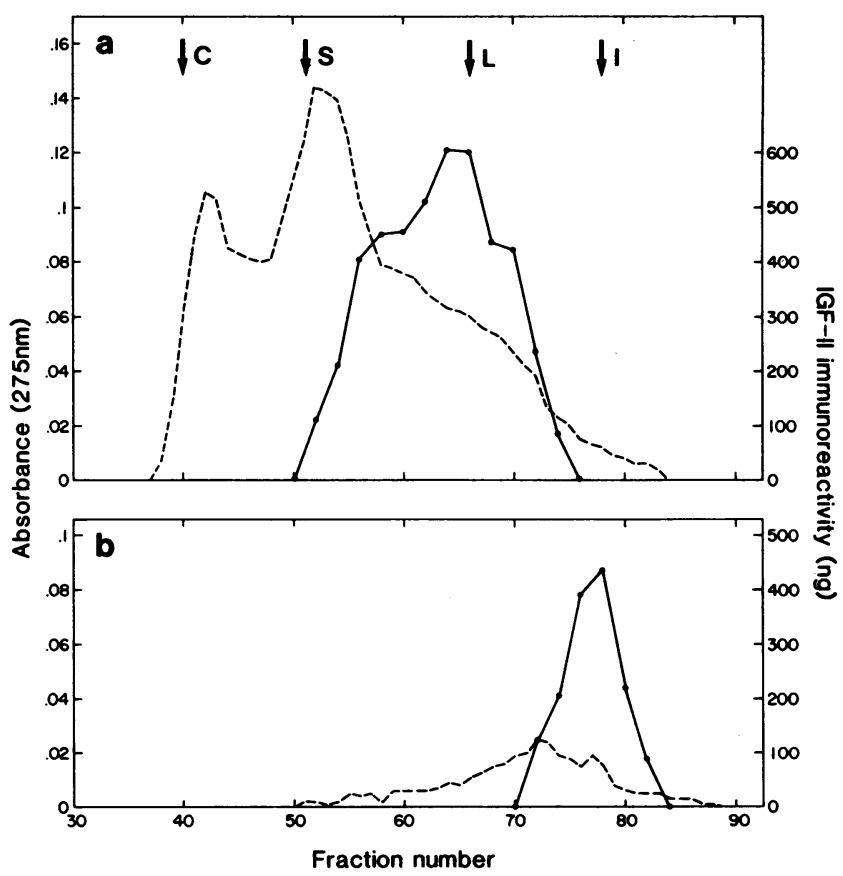

Figure 3. Gel filtration profile and IGF-II immunoreactivity resulting after pooled tumor extracts were re-gel filtered. Extracts were passed through a $90 \times 2.5 \mathrm{~cm}$ Bio-gel P-30 column and eluted with $3 \mathrm{M}$ acetic acid. Absorbance at $275 \mathrm{~nm}$ is indicated by broken lines and IGF-II immunoreactivity by solid lines. (a) 4 pooled higher molecular weight profiles. Fractions 56, 64, and 70 were lyophilized and further analyzed as described in Methods. (b) four pooled lower molecular weight fractions. Fraction 78 was lyophilized and analyzed further as detailed in Methods. The arrows indicate the elution positions of carbonic anhydrase $\left(C, M_{\mathrm{r}} 29,000\right)$, soybean trypsin inhibitor $\left(S, M_{\mathrm{r}}\right.$ $21,000)$, lysozyme $\left(L, M_{\mathrm{r}} 14,000\right)$, and IGF-II $\left(I, M_{\mathrm{r}} 7,500\right)$. 
termediates do not interact with the hydrophobic column or that the mixture of hydrophobic and hydrophilic residues in these extensions are in approximate balance relative to the remainder of IGF-II.

Analysis of IGF-II interactions with serum proteins. To investigate the characteristics of serum IGF-II binding proteins obtained from patients with hypoglycemia, serum that had been incubated with ${ }^{125}$ I-IGF-II was examined by gel filtration. Fig. 4 shows the results of these experiments in two patients and two normal subjects. As can be seen, the profiles obtained from patients and normal subjects were similar. Whereas a small fraction of bound radioactivity eluted in the void volume, the majority of bound radioactivity eluted at a position suggesting interaction of IGF-II with a 30-40000-D binding protein. Small amounts of unbound IGF-II were also seen. It should be noted that the profile obtained from the serum of a third patient exhibited a broader and less well defined peak of ${ }^{125}$ I-IGF-II/binding protein complex after gel filtration. Control studies showed, however, that broad profiles were sometimes seen even in serum from normal subjects when serum had been stored for long periods.

We next undertook to analyze serum IGF-II binding capacity by determining the amount of ${ }^{125}$ I-IGF-II bound to serum proteins after incubation with progressively increasing volumes of patient or normal serum. The results of this experiment are illustrated in Fig. 5. While the percentage of total radioactivity bound by equal volumes of patients and control serum was similar, there was a slight rightward shift in the curves corresponding to patient serum (indicating a binding capacity decreased by about twofold). Nevertheless larger volumes of serum (10-20 $\mu$ l) bound IGF-II similarly both in patient and normal serum.

Having determined the approximate volume of serum that would bind $\sim 40-50 \%$ of ${ }^{125}$ I-IGF-II, we then determined the

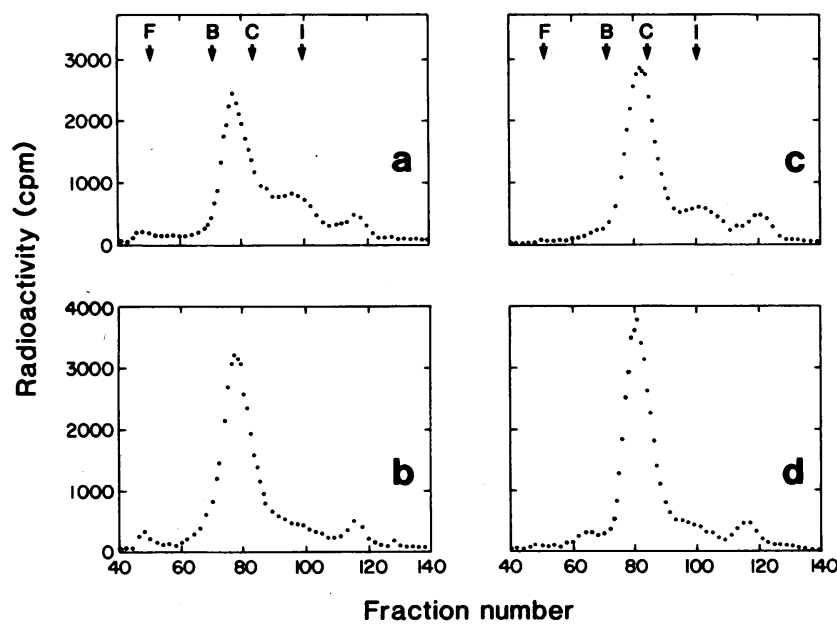

Figure 4. Gel filtration profile resulting from incubation of $\sim 100,000 \mathrm{cpm}$ of ${ }^{125}$ I-IGF-II with patient ( $a$ and $b$ ) or normal ( $c$ and $d$ ) serum. Details of incubation are provided in Methods. Incubated samples were gel-filtered through an Ultrogel AcA $440.9 \times 90$ $\mathrm{cm}$ column. Only fractions containing radioactivity are indicated in the figure. The arrows indicate the relative elution positions of ferritin $\left(F, M_{\mathrm{r}} 500,000\right)$, BSA $\left(B, M_{\mathrm{r}} 68,000\right)$, carbonic anhydrase $\left(C, M_{\mathrm{r}}\right.$ 29,000 ) and free ${ }^{125}$ I-IGF-II (I). To preserve clarity of presentation, only alternate points have been indicated for lower radioactivity values. relative affinities of serum binding proteins from patients and normal subjects for IGF-II. Fig. $6 a$ illustrates that progressively increased concentrations of IGF-II competed for ${ }^{125} \mathrm{I}$ IGF-II binding equally in both patients' and normal serum, with $50 \%$ displacement occurring after the addition of 1-2 ng IGF-II and total displacement occurring after the addition of 20-100 ng.

Since the binding characteristics of patient and control serum for IGF-II were similar, the affinity of serum binding proteins for the various higher molecular forms of IGF-II identified in tumor extracts was determined. Fig. $6 b$ illustrates that IGF-II-related peptides recovered from fractions 64 and 70 from the larger molecular weight profile (Fig. $3 a$ ) and from fraction 78 in the smaller molecular weight profile (Fig. $3 b$ ) bound to serum with similar affinities (on the basis of immunometric equivalency), and that the competition profiles in fact did not differ from the profile obtained by use of authentic IGF-II. For these samples, $50 \%$ of radioactivity bound in the absence of competitor was displaced by $\sim 1 \mathrm{ng}$ of immunometrically quantified IGF-II-related material. In contrast, the IGF-II recovered from fraction 56 (which represented the highest molecular weight form of recovered IGF-II immunoreactivity) demonstrated negligible binding to serum proteins, whether the peptide was incubated with serum from normal subjects or hypoglycemic patients. Indeed, even after the addition of $20 \mathrm{ng}$ of IGF-II immunoreactivity, less than $20 \%$ of bound radioactivity was displaced. Importantly, the equivalent amount of lower molecular weight forms resulted in almost complete inhibition of binding of radiolabeled IGF-II to serum binding proteins.

\section{Discussion}

Suggested mechanisms of tumor hypoglycemia have included increased consumption of glucose by the tumor, or production of factor(s) that may enhance glucose uptake, either by the

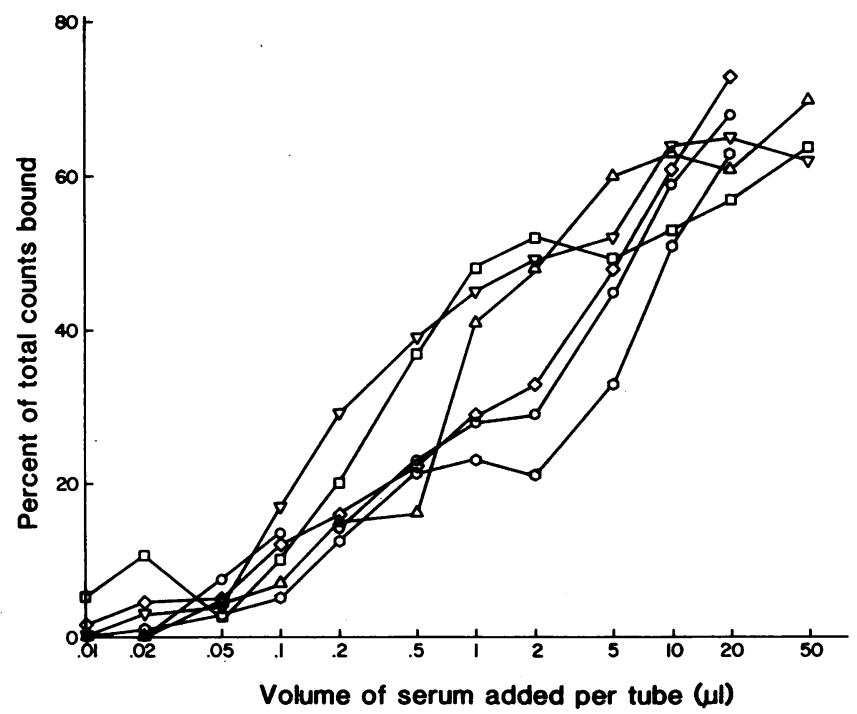

Figure 5. Binding curves resulting from incubation of progressively increasing volumes of normal $(\square \Delta \nabla)$ or patient $(\diamond \circ 0)$ serum with $\sim 12,000 \mathrm{cpm}$ of ${ }^{125}$ I-IGF-II. Details of incubation and precipitation of bound radioactivity is described in Methods. Bound radioactivity is represented as a percentage of total ${ }^{125}$ I-IGF-II added. 


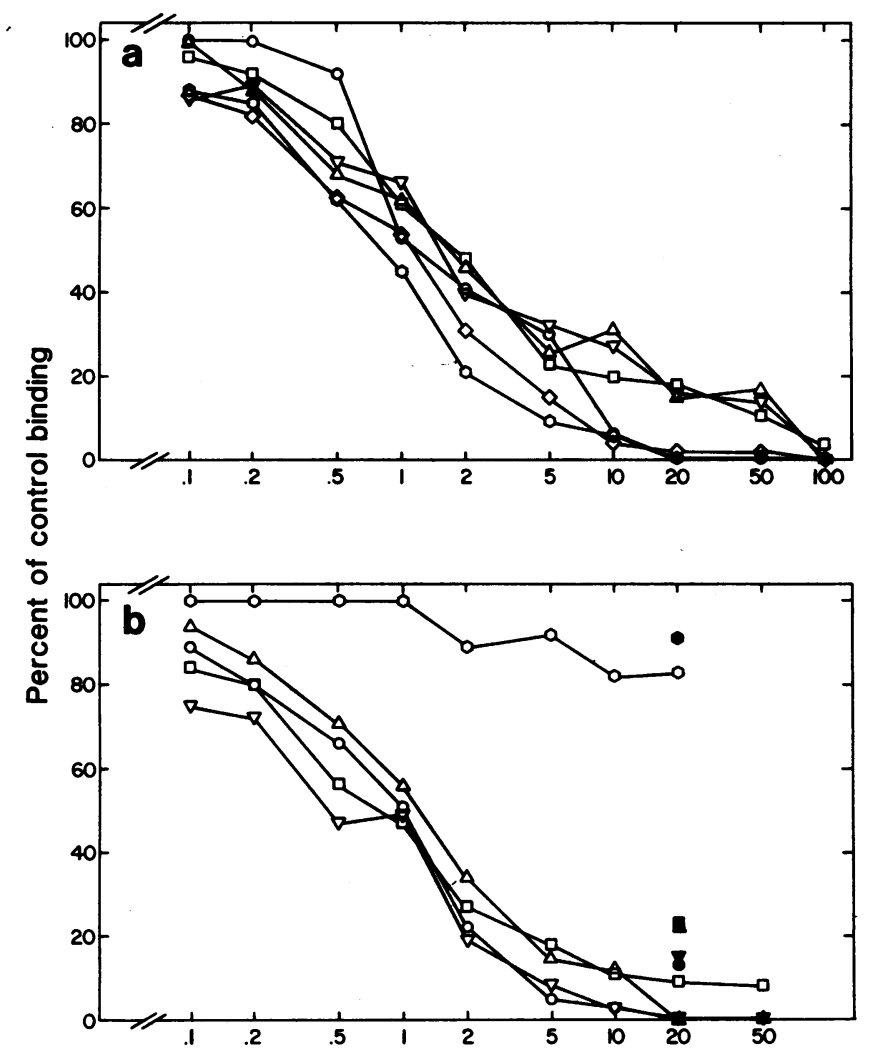

Amount of IGF-II immunoreactivity added per tube (ng)

Figure 6. (a) Competition binding study resulting from the incubation of $2 \mu \mathrm{l}$ of patient serum $(\diamond \circ)$ ) or $1 \mu \mathrm{l}$ of normal serum $(\square \Delta \nabla)$ with $\sim 12,000 \mathrm{cpm}$ of ${ }^{125}$ I-IGF-II and progressively increasing amounts of authentic IGF-II. Binding is represented as percentage of radioactivity associated with serum proteins in the absence of added IGF-II. (b) Competition binding study resulting from incubation of progressively increasing amounts of IGF-II immunoreactivity with 2 $\mu \mathrm{l}$ of patient serum (closed symbols) or $1 \mu \mathrm{l}$ of normal serum (open symbols) from fractions $56(0), 64(\Delta)$, and $70(0)$, identified in Fig. 3 $a$ and fraction $78(\nabla)$ identified in Fig. $3 b$, or authentic IGF-II ( $\square$ ), in the presence of $\sim 12,000 \mathrm{cpm}$ of ${ }^{125}$ I-IGF-II. Percent binding is represented as percent of radioactivity associated with serum proteins in the absence of added IGF-II.

tumor itself or by the periphery. The identification therefore that IGF-II expression is associated with the development of tumor hypoglycemia, has led to the suggestion that this peptide is important in the pathogenesis of this syndrome, and may mediate the development of hypoglycemia (12). The physiological role of IGF-II remains uncertain, however. Although it has not been thought to have a physiological role in carbohydrate metabolism in vivo, injection of IGF-II into hypophysectomized rats (in which levels of binding protein are low), has resulted in insulin-like effects, with development of hypoglycemia and incorporation of $\left[{ }^{14} \mathrm{C}\right]$ glucose into muscle glycogen (27). Thus, notwithstanding the greater blood glucose-lowering activity of IGF-I relative to IGF-II at extended periods after injection (a result potentially arising from the relatively higher affinity of IGF-II for binding proteins with shorter halflives and from an enhanced rate of metabolic clearance), IGFII has been shown under selected circumstances to possess significant insulin-like activity.
To understand the potential relationship between IGF-II and the syndrome of tumor-associated hypoglycemia, two important factors regarding the physiology of this peptide should be borne in mind. First, IGF-II undergoes non-covalent binding to several serum binding proteins with an affinity constant approximately between 0.1 and $1 \mathrm{nM}(28,29)$. In fact it has been estimated that less than $1 \%$ of total IGF-II circulates freely. Second, binding of IGF-II to its carrier proteins inhibits transport across capillaries and prevents access to cell surface receptors, thus rendering it metabolically inactive (30-32). Therefore, although an association between enhanced IGF-II expression in tumors associated with hypoglycemia has been made, $(a)$ levels in serum have not been elevated above normal, (b) after resection of the tumor, serum levels may not be lower than those measured before operation, $(c)$ free IGF-II in serum has not been detected in these patients, and $(d)$ it is probable that the potency of IGF-II in producing hypoglycemia is low.

Although we have found no suggestion for differences in the character, functional binding capacity or affinity of serum binding proteins for IGF-II among hypoglycemic patients and normal subjects, the presence of higher molecular weight forms of IGF-II in the sera of hypoglycemic patients (reference 12 and this report) represents a matter of considerable interest. Our demonstration of increased IGF-II expression in hepatic tumors of hypoglycemic patients, and our identification of higher molecular weight IGF-II immunoreactivity, which has a substantially reduced affinity for binding to serum binding protein, may explain the apparent paradox. These data suggest that a small proportion of this higher molecular weight IGF-II may circulate free under physiological circumstances, and thus may be available for interaction with cell surface receptors either in its native forms or after processing in the extracellular space. Although we could not measure free IGF-II levels in these patients due to the limited amount of serum available, the significance of this finding is highlighted by considering that if only $10 \%$ of total serum IGF-II immunoreactivity consisted of IGF-II with a negligible affinity for serum binding proteins, the peptide would circulate at a concentration of $\sim 40 \mathrm{ng} / \mathrm{ml}$. A direct analysis of the abilities of these peptides to interact with cell-surface receptors that might play a role in glucose utilization must await an opportunity to obtain greater amounts of tumor or other tissue expressing the IGF-II gene.

Reduced affinity of IGF-II-related peptides for serum binding proteins may result either from the altered structure of a higher molecular weight IGF-II, such that its conformation precludes binding, or from proteolytic cleavage at a site important for interaction with binding proteins during metabolism to conversion intermediates. The sequence of higher molecular weight IGF-II-related peptides predicted from the cDNA project that there might be a variable degree of extension of the carboxyl terminus in these forms. On one hand cleavage at any of a number of paired or single dibasic residues in the extended precursor peptide could account for the heterogeneous forms of IGF-II observed. On the other hand, small changes in the amino terminal region of IGF-I have been shown to decrease the affinity of ligand for the serum binding protein (33). The characteristics of the higher molecular weight form of IGF-II with poor affinity for the binding protein could well arise from the simultaneous existence of a large carboxyl terminal extention and a short amino terminal deletion. Although insufficient amounts of material were available for fur- 
ther characterization, we have found that all of these forms dilute in parallel in the IGF-II radioimmunoassay. Several similar peptides have been detected in the serum, tissue or cell culture medium $(12,34-37)$. Our results are consistent with those of Gowan et al. who showed that an unusual, intermediate molecular weight form of IGF-II isolated from human serum Cohn fraction IV associated with serum binding proteins with the same affinity as that exhibited by IGF-II itself (36). Although our analysis emphasizes interaction of IGF-II with the most available low molecular weight binding protein present in serum, several serum binding proteins with differing relative affinities for ligand and different half-lives are known to exist (27). Further studies are therefore needed to address the full range of potential interactions of the various forms of IGF-II identified here with the multiple proteins to which they might bind in serum.

Whereas the low IGF-I levels in our patients are not readily explained, this finding has been reported in previous studies of tumor associated hypoglycemia $(9,12)$. Although the suggestion has been made that low IGF-I levels are a consequence of suppressed growth hormone secretion, growth hormone levels were not demonstrated to be low in all of our patients. It is possible that their liver disease and altered nutritional state may have contributed to low IGF-I levels (38).

To maintain plasma glucose at normal levels in patients with tumor hypoglycemia, daily glucose requirements of as much as $1.6 \mathrm{~kg}$ have been reported (1). Since the normal rate of hepatic glucose output is $\sim 2-2.5 \mathrm{mg} / \mathrm{kg}$ per $\min (39,40)$, the hypoglycemia cannot result from reduced hepatic glucose output alone and glucose uptake must be increased to a substantial degree. However it remains to be seen whether the mechanism of hypoglycemia involves $(a)$ stimulation of the insulin receptor, $(b)$ stimulation of the IGF-I receptor, $(c)$ stimulation of the IGF-II receptor or $(d)$ another mechanism. Although analysis of the IGF system is made difficult both by the presence of serum binding proteins and by receptor crossreactivities, and although the pharmacodynamics of IGF action are, therefore, necessarily complex, our findings provide a mechanistic framework for the future consideration of the relationship between IGF-II gene expression and tumor hypoglycemia.

\section{Acknowledgments}

We are indebted to William Daughaday and Milan Kapadia for measurement of serum and tumor IGF-II levels and for valuable discussions and suggestions, Marsha Davenport for measurement of IGF-I levels, Vanessa Panz for determination of GH concentrations, Allan Eisenberg for providing samples from the patient presenting with the hemangiopericytoma and to Sandra Kancauski and Virginia Kuvakos for expert secretarial assistance.

This work was supported in part by grants DK-18347, DK-31842, and DK-13941 from the National Institutes of Health, the Diabetes Research and Training Center of the University of Chicago (DK-20595) and the Howard Hughes Medical Institute. Dr. Polonsky is the recipient of a Research Career Development Award from the National Institutes of Health (DK 01234).

\section{References}

1. McFadzean, A. J. S., and R. T. T. Yeung. 1969. Further observations on hypoglycaemia in hepatocellular carcinoma. Am. J. Med. 47:220-235.
2. Unger, R. H. The riddle of tumor hypoglycemia. 1966. Am. J. Med. 40:325-330.

3. Chandalia, H. B., and B. R. Boshell. 1972. Hypoglycemia associated with extrapancreatic tumors. Arch. Intern. Med. 129:447-456.

4. Kahn, C. R. 1980. The riddle of tumor hypoglycemia revisited. Clin. Endocrinol. Metab. 9:335-360.

5. Megyesi, K., C. R. Kahn, J. Roth, and P. Gorden. 1974. Hypoglycemia in association with extrapancreatic tumors: demonstration of elevated plasma NSILA-s by a new radioreceptor assay. J. Clin. Endocrinol. Metab. 38:931-934.

6. Megyesi, K., C. R. Kahn, J. Roth, and Gorden P. 1975. Circulating NSILA-s in man: preliminary studies of stimuli in vivo and of binding to plasma components. J. Clin. Endocrinol. Metab. 41:475484 .

7. Hyodo, T., K. Megyesi, C. R. Kahn, J. P. McLean, and H. G. Friesen. 1977. Adrenocortical carcinoma and hypoglycemia: evidence for production of nonsuppressible insulin-like activity by the tumor. $J$. Clin. Endocrinol. Metab. 44:1175-1184.

8. Gorden, P., C. M. Hendricks, C. R. Kahn, K. Megyesi, and J. Roth. 1981. Hypoglycemia associated with non-islet-cell tumor and insulin-like growth factors. A study of the tumor types. N. Engl. J. Med. 305:1452-1455.

9. Daughaday, W. H., B. Trivedi, and M. Kapadia. 1981. Measurement of insulin-like growth factor II by a specific radioreceptor assay in serum of normal individuals, patients with abnormal growth hormone secretion, and patients with tumor-associated hypoglycemia. J. Clin. Endocrinol. Metab. 53:289-294.

10. Zapf, J., H. Walter, and E. R. Froesch. 1981. Radioimmunological determination of insulinlike growth factors I and II in normal subjects and in patients with growth disorders and extrapancreatic tumor hypoglycemia. J. Clin. Invest. 68:1321-1330.

11. Widmer, U., J. Zapf, and E. R. Froesch. 1982. Is extrapancreatic tumor hypoglycemia associated with elevated levels of insulin-like growth factor II? J. Clin. Endocrinol. Metab. 55:833-839.

12. Daughaday, W. H., M. A. Emanuele, M. H. Brooks, A. L. Barbato, M. Kapadia, and P. Rotwein. 1988. Insulin-like growth factor II synthesis and secretion by a leiomyosarcoma with associated hypoglycemia. N. Engl. J. Med. 319:1434-1440.

13. Hintz, R. L., E. M. Orsini, and M. G. Van Camp. 1974. Demonstration of reversible binding of somatomedin to plasma proteins. Endocrinology. 94(suppl):A-71.

14. Zapf, J., M. Waldvogel, and E. R. Froesch. 1975. Binding of NSILA to human serum: evidence for a carrier protein. Arch. Biochem. Biophys. 168:638-645.

15. Hintz, R. L., and F. Liu. 1977. Demonstration of specific plasma protein binding sites for somatomedin. J. Clin. Endocrinol. Metab. 45:988-995.

16. Ullrich, A., J. Shine, J. Chirgwin, R. Pictet, E. Tischer, W. J. Rutter and H. M. Goodman. 1977. Rat insulin genes: construction of plasmids containing the coding sequence. Science (Wash. DC). 196:1313-1319.

17. Bell, G. I., J. H. Karam, and W. J. Rutter. 1981. A polymorphic DNA region adjacent to the 5 ' end of the human insulin gene. Proc. Natl. Acad. Sci. USA. 78:5759-5763.

18. Bell, G. I., J. P. Merryweather, R. Sanchez-Pescador, M. M. Michelle, M. Stempien, L. Priestley, J. Scott, and L. B. Rall. 1984. Sequence of a cDNA clone encoding human preproinsulin-like growth factor II. Nature (Lond.). 310:775-777.

19. Fukumoto, H., S. Seino, H. Imura, Y. Seino, R. L. Eddy, Y. Fukushima, M. G. Byers, T. B. Shows, and G. I. Bell. 1988. Sequence, tissue distribution, and chromosomal localization of mRNA encoding a human glucose transporter-like protein. Proc. Natl. Acad. Sci. USA. 85:5434-5438.

20. Maniatis, T., E. F. Fritsch, and J. Sambrook. 1982. Molecular cloning: A laboratory manual. Cold Spring Harbor Laboratory, Cold Spring Harbor, NY.

21. Little, P. F. R., and I. J. Jackson. 1987. Application of plasmids containing promoters specific for phage-encoded RNA polymerases. 
In DNA cloning. Vol III: a practical approach. D. M. Glover, editor. IRL Press, Washington, DC. 1-18.

22. Morgan, C. R., and A. Lazarow. 1963. Immunoassay of insulin: two antibody systems: plasma insulin levels of normal, subdiabetic and diabetic rats. Diabetes. 12:115-126.

23. Davenport, M. L., M. E. Svoboda, K. L. Koerber, J. J. Van Wyk, D. R. Clemmons, and L. E. Underwood. 1988. Serum concentrations of insulin-like growth factor II are not changed by short term fasting and refeeding. J. Clin. Endocrinol. Metab. 67:1231-1236.

24. Copeland, K. C., L. E. Underwood, and J. J. Van Wyk. 1980. Induction of immunoreactive somatomedin $\mathrm{C}$ in human serum by growth hormone: dose-response relationships and effect on chromatographic profiles. J. Clin. Endocrinol. Metab. 50:690-697.

25. Daughaday, W. H. 1987. Radioligand assay for insulin-like growth factor II. Methods Enzymol. 146:248-259.

26. Shoelson, S., M. Haneda, P. Blix, A. Nanjo, T. Sanke, K. Inouye, D. Steiner, A. Rubenstein, and H. Tager. 1983. Three mutant insulins in man. Nature (Lond.). 302:540-543.

27. Zapf, J., C. Hauri, M. Waldvogel, and E. R. Froesch. 1986. Acute metabolic effects and half-lives of intravenously administered insulinlike growth factors I and II in normal and hypophysectomized rats. J. Clin. Invest. 77:1768-1775.

28. Hintz, R. L., and F. Liu. Somatomedin plasma binding proteins. In Growth Hormone and Other Biologically Active Peptides. A Pecille and E. E. Muller, editors. Excerpta Medica, Amsterdam. 133-143.

29. Daughaday, W. H., A. P. Ward, A. C. Goldberg, B. Trivedi, and M. Kapadia. 1982. Characterization of somatomedin binding in human serum by ultracentrifugation and gel filtration. J. Clin. Endocrinol. Metab. 55:916-921.

30. Zapf, J., E. Schoenle, G. Jagars, I. Sand, J. Grunwald, and E. R. Froesch. 1979. Inhibition of the action of non-suppressible insulin-like activity on isolated fat cells by binding to its carrier protein. J. Clin Invest. 63:1077-1084.

31. Drop, S. L. S., G. Valiquette, H. J. Guyda, M. T. Corvol, and
B. I. Posner. 1979. Partial purification and characterization of a binding protein for insulin-like activity (ILAs) in human amniotic fluid: a possible inhibitor of insulin-like activity. Acta Endocrinol. 90:505518.

32. Meuli C., J. Zapf, and E. R. Froesch. 1978. NSILA-carrier protein abolishes the action of non-suppressible insulin-like activity (NSILA-S) on perfused rat heart. Diabetologia. 14:255-259.

33. Bayne, M. L., J. Applebaum, G. G. Chicchi, N. S. Hayes, B. G. Green, and M. A. Cascieri. 1988. Structural analysis of human insulin-like growth factor I with reduced affinity for serum binding proteins and the type 2 insulin-like growth receptor. J. Biol. Chem. 263:62336239.

34. Moses, A. C., S. P. Nissley, P. A. Short, M. M. Rechler, and J. M. Podskalny. 1980. Purification and characterization of multiplication-stimulating activity. Eur. J. Biochem. 103:387.

35. Zumstein, P. P., C. Luthi, and R. Humbel. 1985. Amino acid sequence of a variant pro-form of insulin-like growth factor II. Proc. Natl. Acad. Sci. USA. 82:3169.

36. Gowan, L. K., B. Hampton, D. J. Hill, R. J. Schlueter, and J. F. Perdue. 1987. Purification and characterization of a unique high molecular weight form of insulin-like growth factor II. Endocrinology. 449-458.

37. Tanaka, H., A. Osamu, T. Hayano, I. Sasaki, Y. Yoshitake, and K. Nishikawa. 1989. Identification of a family of insulin-like growth factor II secreted by cultured rat epithelial-like cell line 18,54-SF: application of a monoclonal antibody. Endocrinology. 124:870-877.

38. Phillips, L. S., and R. Vassipoulou-Sellin. 1979. Nutritional regulation of somatomedin. Am. J. Clin. Nutr. 32:1082-1096.

39. Garber, A. J., P. E. Cryer, J. V. Santiago, M. W. Haymond, A. S. Pagliara, and D. M. Kipnis. 1976. The role of adrenergic mechanisms in the substrate and hormonal response to insulin-induced hypoglycemia in man. J. Clin. Invest. 58:7-15.

40. Searle, G. L. 1976. The use of isotope turnover techniques in the study of carbohydrate metabolism in man. Clin. Endocrinol. Metab. 5:783-804. 